\title{
SOCIAL MEDIA ADDICTION IN TERMS OF GENDER IN JUNIOR HIGH SCHOOL
}

\author{
Hardiyansyah Masya*, Tri Dewantari, Chika Meryando \\ *Correspondent Author
}

\author{
Hardiyansyah Masya \\ Universitas Islam Negeri Raden Intan \\ Lampung \\ Jalan Letnan Kolonel H Jl. Endro \\ Suratmin, Sukarame, Kota Bandar \\ Lampung \\ Indonesia \\ Email: \\ hardiyansyahmasya@radenintan.ac.id \\ Tri Dewantari \\ STKIP Al-Islam Tunas Bangsa \\ Jalan ZA. Pagar Alam Nomor 41, Bandar \\ Lampung \\ Indonesia \\ Email: tridewantari@stkipalitb.ac.id \\ Chika Meryando \\ Universitas Islam Negeri Raden Intan \\ Lampung \\ Jalan Letnan Kolonel H Jl. Endro \\ Suratmin, Sukarame, Kota Bandar \\ Lampung \\ Indonesia \\ Email: chikameryando@gmail.com
}

\begin{abstract}
The purpose of this study was to examine the relationship between social media addiction in terms of gender in junior high school students. This research is quantitative research with correlation research type. This study was conducted at SMPN 19 Bandar Lampung, with the research subjects as many as 60 students, 30 male students and 30 female students. Taking the research subject using purposive sampling with the category of students who have an addiction to social media. This study uses a social media addiction scale. Data analysis using phi correlation. The results of this research hypothesis test in 0.05 (0.026> (0.05), which means that there is a correlation between social media addiction in terms of gender. The study results can be used as for guidance and counseling teachers or counselors to provide guidance and counseling services about social media addiction.
\end{abstract}

Keywords: gender, junior high school, social media

Page

79-83

\section{INTRODUCTION}

Many people enjoy technological innovations that have been produced by technological media (Ngafifi, 2014). The advanced technology development facilitates people's daily activities such as finding basic information, communication access has also been widely used in the community called social media. Because the use of social media allows anyone to access and use social media. Distance, time to meet friends or family is no longer a barrier, social media can facilitate this (Watie, 2016). By using social media to communicate, looking for news, as entertainment, distance is not a barrier for people who can access social media.

Social media allow users to participate, share in blogs, social networks, wikis, forums and virtual worlds. (Cahyono, 2016). Social Media allows its users to write or express themselves, share, interact, communicate with other users (Setiadi, 2016). The use of social media turns conventional communication into interactive dialogue using web-based technology as a communication tool.

The use of social media in Indonesia rapidly grows. According to the Global Web 


\title{
80| PSIKOPEDAGOGIA
}

\author{
JURNAL BIMBINGAN DAN KONSELING
}

Vol.10, No.2, December 2021

Index Data in 2014 (EB \& SW, 2017), Indonesia is a country with the most active social media users compared to other countries. The use of social media in Indonesia is $79.7 \%$, followed by Philippines (78\%), Malaysia (72\%), and China (67\%). Social media is not only accessed by adults but teenagers also use social media with quite a large number. Based on data from google consumer behavior (Supratman, 2018) 50\% of Indonesia's population of 265.4 million are internet users, with half of the users being adolescents. This data is reinforced by the results of a survey by Frontier Consulting Group Indonesia which states that $91.2 \%$ of adolescents aged 13-19 are active social media users (EB \& SW, 2017). Based on this, it can be seen that the use of social media in adolescents is also very fast.

The widespread use of social media that occurs among teenagers can have an impact on the lives of these teenagers, the resulting impact can be negative or positive, this depends on the purpose and intensity of its use. The positive impact on adolescents who actively use the internet is that it can expand their network of friends, making it easier for teens to find information (Putri, Nurwati, \& Budiarti, 2016). In addition, one of the impacts that occur on adolescents who spend a lot of time playing social media is that it causes teenagers to be lazy to do physical activities so that it will affect their interactions with the surrounding environment. (Setiawati, et al., 2019).

When viewed by gender there are differences in social media addiction in men and women. Based on research results Nur et al. (2014) There are differences in the use of social media for boys and girls. Based on this study, the intensity of social media use tends to be more time for female respondents. Meanwhile, for male respondents, the use of the internet for social media tends to be small because most of it is used to find information and play games. In line with this research, research conducted by Mulyati \& Frieda (2019) which states that there are differences in the use of social media by using smartphones between men and women. The use of social media using smartphones in women tends to be higher than men.

Based on the phenomenon that occurred and a review of the results of the related studies that have been described, the researchers felt the need to conduct deeper research related to the use of social media based on gender. The study results can be used as a basis for guidance and counseling teachers or counselors to provide guidance and counseling services. counseling about social media addiction.

\section{RESEARCH METHOD}

This research is quantitative research with correlation research, this study looks at whether or not there is a relationship between variables. This research was conducted at SMPN 19 Bandar Lampung, with the research subjects as many as 60 students, 30 male students and 30 female students. Sampling using purposive sampling technique with categories of students who are indicated to have experienced addiction to the use of social media, the sample is determined after distributing the Likert scale to students. The research instrument used in this study used a Likert scale which was used to measure the level of social media addiction in students. Data analysis using phi correlation.

\section{RESULT AND DISCUSSION}

Descriptions of the results of this study were obtained based on data obtained from the Likert scale distribution and analyzed using variate analysis and bivariate analysis. Based on the analysis of social media addiction in students, the initial conditions of students showed that most of the conditions for social media addiction in male students were in the low, high and medium categories. 
Table 1

Frequency Distribution of Social Media Addiction in Male Students

\begin{tabular}{|c|c|c|c|}
\hline Category & $\begin{array}{l}\text { Score } \\
\text { Range }\end{array}$ & Frequency & Percentage \\
\hline High & $X>75$ & 10 & $33 \%$ \\
\hline Moderate & $\begin{array}{c}50 \delta \times \delta \\
75\end{array}$ & 7 & $23 \%$ \\
\hline Low & $\times \delta 50$ & 13 & $44 \%$ \\
\hline \multicolumn{2}{|c|}{ Total } & 30 & $100 \%$ \\
\hline
\end{tabular}

Table with permission @Data Primer. 2019.

Based on the data in table 1, it can be seen that of the 30 male students who were sampled, $44 \%$ of the students were in a low category, $33 \%$ of the students were in the high category and $23 \%$ of the students were in the medium category. Different conditions are seen in female students, most of whom are in the medium, high, low category.

Table 2

Frequency Distribution of Social Media Addiction in Famale

\begin{tabular}{cccc}
\hline Category & $\begin{array}{c}\text { Score } \\
\text { Range }\end{array}$ & Frequency & Percentage \\
\hline High & $\mathrm{X}>75$ & 12 & $40 \%$ \\
\hline Moderate & $\begin{array}{c}50 \delta \mathrm{X} \\
\delta 75\end{array}$ & 14 & $47 \%$ \\
\hline Low & $\mathrm{X} \delta 50$ & 4 & $13 \%$ \\
\hline \multicolumn{2}{c}{ Total } & $\mathbf{3 0}$ & $\mathbf{1 0 0 \%}$ \\
\hline
\end{tabular}

Based on the data in table 2 it can be seen that of the 30 female students who were sampled, $47 \%$ of the students were in the medium category, $40 \%$ of the students were in the high category and $13 \%$ of the students were in a low category.

Table 3

Results Of The Correlation Analysis

\begin{tabular}{llrr}
\hline & & Value & \multicolumn{1}{c}{$\begin{array}{c}\text { Approx. } \\
\text { Sig. }\end{array}$} \\
\hline Nominal & Phi &, 348 &, 026 \\
by & Cramer's V &, 348 &, 026 \\
Nominal & Contingency &, 329 &, 026 \\
& Coefficient & & \\
N of Valid Cases & 60 & \\
\hline
\end{tabular}

Based on table 3, it was found that there was a correlation between social addiction and the gender of students. This can be seen from the significant correlation results, namely, the significance value is greater than $0.05(0.026>(0.05)$, which means that there is a correlation between gender and social media addiction. In other words, the research hypothesis is accepted. There is a correlation between gender and social media addiction in students at SMP 19 Bandar Lampung. This is evident from the results of the research hypothesis test which shows that $\mathrm{Ho}$ is rejected and $\mathrm{H} 1$ is accepted, so it can be concluded that there is a relationship between gender and social media addiction.

The results showed that there was a relationship between social media addiction and gender in students of SMPN 19 Bandar Lampung. This is in line with the results of research by Paska and Yan (Mulyati \& Frieda, 2019) It was revealed that there are several factors that influence the occurrence of internet addiction, namely gender, purpose, time of use, economic conditions and psychological conditions. Although gender is one of the factors influencing internet use, it turns out that men and women have different time intensities.

The results of the distribution of the anxiety scale show that female students are more likely to use social media than male students. This is in line with research Lestari, Dewi, \& Chairani (2020) which revealed that the time spent by young girls to use social media is more than that of boys because in this case, women like to tell stories, express their feelings, and communicate with other people, social media can make them reduce stress. This is in line with research Majorsy et al. (2013) which states that they are more likely to like to tell stories, like to communicate, this is because women tend to be judged to have higher social skills than men. Meanwhile, male teenagers usually use social media to play games. Boys in social media are more likely to use social media to play games, pornography and social networking (Zegarra Zamalloa \& Cuba Fuentes, 2017).

Social media that is currently widely used among teenagers, namely Facebook, Twitter, Instagram, this is because these features are free, easy for anyone to download, and can make it easier to communicate and find information (Fitri, 2017). In line with this opinion, the results of other studies reveal that students at the junior high school level mostly have smartphones in which there are Facebook, Twitter, Instagram, Google+, and 


\section{2| PSIKOPEDAGOGIA}

JURNAL BIMBINGAN DAN KONSELING

Vol.10, No.2, December 2021

Linkedln accounts, and some students when observed what are the reasons they use various social media, namely follow trends and get recognized by their friends (Basri \& Syafrizal, 2017). The widespread use of social media is undeniable due to several influencing factors such as ease of use, utility factors, facilitating personal and social networks, factors relating to social media and daily activities (Destiana, Salman, \& Rahim, 2013). The results of other studies state that the motive for using social media among students is the motive of information, in this case students use social media to find information and materials for studying or doing homework, personal identity motives, in this case adolescents use social media for existence and slang, integration motives for interacting with others, and entertainment motives for playing games and others (Intan, 2015).

Based on the influencing factors, social media will have a positive impact if it is used according to its benefits and with an intensity that is not excessive. This is in line with the research results (Mariskhana, 2018) gadgets have a great impact on students both in terms of learning motivation and student behaviour. This really depends on what students do in playing social media. If the application that is seen or played is an educational application, it can build students' creativity and learning motivation, but if the application that is seen contains negative things such as violence and pornography, it will harm students. In line with this research-based on research Hidajat, et al. (2015) which states that with the emergence of social media, there have been more cases of cyber bullying by students by distributing videos, texts, and images that mock and demean others.

The intensity of the use of social media in adolescents, if not addressed, will cause adolescents to experience addiction to social media. Characteristics of adolescents who experience addiction to social media according to Young (Ihsan, 2016) that is, the addict's mind is only fixated on the internet / social media activities, it is difficult to focus on other things, the intensity of the continuous use of social media, it is difficult to control himself in reducing social media use, is uncomfortable when trying to stop the use of social media, uses social media exceeds the targeted time, use of internet / social media at risk of eliminating jobs, study opportunities, and careers, risk of lying to family, therapists to hide excessive involvement in social media use, use of social media/internet to escape problems and negative feelings other. Teens who exhibit these characteristics can be categorized as adolescents who experience addiction to social media.

Referring to the results of research and previous research, it can be concluded that there is a relationship between social media addiction and gender. This is because there are differences in the purpose and intensity of time used by teenage boys and girls in using social media. Boys tend to use social media to play games while girls tend to use social media to tell stories and exchange news.

\section{CONCLUSION}

Based on the findings of the study, it was concluded that there was a relationship between social media addiction and gender in students of SMPN 19 Bandar Lampung. In other words, there are differences in the use of social media for male and female students. In male students, the use of social media tends to play games, while female students tend to use social media to tell stories and exchange news.

From the results of the research conclusions, the suggestions offered from the results of this study are that counselors or guidance and counseling teachers in schools can provide services to students who experience internet addiction. Further researchers can make this study a reference regarding the relationship between internet addiction and the gender of the educated participants.

\section{ACKNOWLEDGEMENT}

Thank you to Raden Intan Lampung State Islamic University, and colleagues who have helped in this research process. This manuscript is the result of research conducted by researchers in Lampung Province. 


\section{REFERENCES}

Basri, H., \& Syafrizal, S. (2017). Peran Media Sosial Twitter Dalam Interaksi Sosial Pelajar Sekolah Menengah Pertama Di Kota Pekanbaru (Studi Kasus Pelajar SMPN 1 Kota Pekanbaru). Riau University.

Cahyono, A. S. (2016). Pengaruh Media Sosial Terhadap Perubahan Sosial Masyarakat di Indonesia. Jurnal Publiciana, 9(1), 140-157.

Destiana, I., Salman, A., \& Rahim, M. H. A. (2013). Penerimaan Media Sosial: Kajian dalam Kalangan Pelajar Universiti di Palembang. Jurnal Komunikasi: Malaysian Journal of Communication, 29(2).

EB, G. A., \& SW, E. D. (2017). Hubungan Penggunaan Media Sosial dengan Tingkat Kepekaan Sosial di Usia Remaja. Jurnal The Messenger, 9(1), 65-69.

Fitri, S. (2017). Dampak Positif Dan Negatif Sosial Media Terhadap Perubahan Sosial Anak: Dampak Positif Dan Negatif Sosial Media Terhadap Perubahan Sosial Anak. Naturalistic: Jurnal Kajian Penelitian Pendidikan Dan Pembelajaran, 1(2), 118-123.

Hidajat, M., et al. (2015). Dampak Media Sosial dalam Cyber Bullying. ComTech: Computer, Mathematics and Engineering Applications, 6(1), 72-81.

Ihsan, M. (2016). Pengaruh Terpaan Media Internet dan Pola Pergaulan Terhadap Karakter Peserta Didik. Tsamrah AlFikri, 10, 103-120.

Intan, T. (2015). Motif Pelajar SMAN 1 Wungu Madiun dalam Penggunaan Media Sosial. Komunikatif, 4(1), 42-63.

Lestari, Y. M., Dewi, S. Y., \& Chairani, A. (2020). Hubungan Alexithymia dengan Kecanduan Media Sosial pada Remaja di Jakarta Selatan. SCRIPTA SCORE Scientific Medical Journal, 1(2), 9.

Majorsy, U., et al. (2013). Hubungan antara keterampilan sosial dan kecanduan situs jejaring sosial pada masa dewasa awal. Prosiding PESAT, 5.

Mariskhana, K. (2018). Dampak Media Sosial (Facebook) dan Gadget Terhadap Motivasi Belajar. Jurnal Perspektif, 16(1), 62-67.

Mulyati, T., \& Frieda, N. R. H. (2019). Kecanduan Smartphone Ditinjau Dari Kontrol Diri dan Jenis Kelamin pada Siswa SMA Mardisiswa Semarang. Empati, 7(4), 152-161.
Ngafifi, M. (2014). Kemajuan teknologi dan Pola Hidup Manusia dalam Perspektif Sosial Budaya. Jurnal Pembangunan Pendidikan: Fondasi Dan Aplikasi, 2(1).

Nur, A., et al. (2014). Pengaruh Usia, Tingkat Pendidikan, dan Jenis Kelamin terhadap perilaku Konsumsi Media. Interaksi Online, 2(4).

Putri, W. S. R., Nurwati, N., \& Budiarti, M. (2016). Pengaruh Media Sosial Terhadap Perilaku Remaja. Prosiding Penelitian Dan Pengabdian Kepada Masyarakat, 3(1).

Setiadi, A. (2016). Pemanfaatan Media Sosial untuk Efektifitas Komunikasi. Cakrawala-Jurnal Humaniora, 16(2).

Setiawati, F. S., et al. (2019). Intensitas Penggunaan Media Sosial, Kebiasaan Olahraga, dan Obesitas Pada Remaja Di SMA Negeri 6 Surabaya Tahun 2019. Amerta Nutrition, 3(3), 142-148.

Supratman, L. P. (2018). Penggunaan Media Sosial oleh Digital Native.

Watie, E. D. S. (2016). Komunikasi dan Media Sosial (Communications and Social Media). Jurnal The Messenger, 3(2), 69-74.

Zegarra Zamalloa, C. O., \& Cuba Fuentes, M. S. (2017). Frequency of Internet addiction and development of social skills in adolescents in an urban area of Lima. Medwave, 17(01). 